\title{
都市下水処理を行うMBRにおける膜ファウリング物質の起源
}

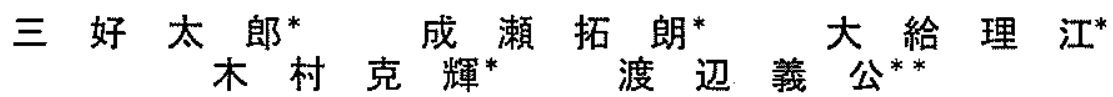

\section{Origin of Foulants in Membrane Bioreactors (MBRs) Treating Municipal Wastewater}

\author{
Taro MIYOSHI*, Takuro NARUSE* ${ }^{*}$, Rie OGYU*, \\ Katsuki KIMURA* and Yoshimasa WATANABE** \\ * Division of Built Environment, Graduate School of Engineering, Hokkaido University, N13 W8, Kita-ku, Sapporo, Hokkaido 060-8628 Japan \\ * * Center for Environmental Nano \& Bio Engineering in Hokkaido University, N13 W8, Kita-ku, Sapporo, Hokkaido 060-8628 Japan
}

\begin{abstract}
The origin of foulants that causes physically irreversible fouling in pilot-scale membrane bioreactors (MBRs) treating real municipal wastewater was investigated. Utilization-associated products (UAP), biomass-associated products (BAP), and organic matter contained in the raw wastewater could be considered as potential sources of foulants in MBRs. Organic matter contained in the raw wastewater and BAP were characterized to assess their contributions to the evolution of physically irreversible fouling. Fourier transform infrared (FTIR) analysis, fluorescence excitation-emission matrices (EEM), and monosaccharide/amino acid composition analysis were used to characterize the organic matter. The results revealed that the organic matter contained in the raw wastewater was minor among the foulants regardless of the SRT. The characteristics of the foulant of the MBR operated with a long SRT were relatively similar to those of BAP, while no obvious similarity was observed between the characteristics of BAP and that of the foulant in the MBR operated with a short SRT. It was suggested that the contribution of UAP to the physically irreversible fouling increases as the SRT is shortened. The foulant of the MBR operated with a short SRT exhibited a higher specific filtration resistance than that of the MBR operated with long SRT. UAP causes severe physically irreversible fouling and it is important to minimize the accumulation of UAP in the mixed liquor of MBRs.
\end{abstract}

Key words : Membrane Bioreactor (MBR), physically irreversible fouling, origin of foulant

\section{1.はじめに}

膜分離活性污泥法(Membrane Bioreacotor; MBR)忙，標蕉 活性污泥法に代表される既存の下水処理システムと比較

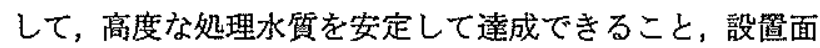
櫝が小さいこと, 自動化を含めた通転管理が容易であるこ と，細菌を全く含まない処理水が得られることといった利 点を有しており，今後より広籁な利用が期待されているいー4)。 しかし，MBRは连転の継続に伴い膜の閉塞(膜ファウリン グうの発生によって膜透過性能が焦下するという問題を抱 えている。膜透過性能が低下することによって所要㲜力の 增加や膜の洗浄にかかる費用の増加など, 運転及び維持管 理コストが増加するため，膜ファウリングの進行を抑制す ることが重要である。

膜ファウリングは逆流洗浄に代表される物理洗浄によ つて解消できる物理的に可逆的な膜ファウリングと，物理 洗浄では解消できず, 薬品洗浄を行うことによってのみ解 消できる物理的に不可逆的な膜ファウリングの2種類に大 きく分類することができるら 。物理的に可逆的な膜ファウ
リングは，運転サイクルに適切な物理洗浄を組み込むこと でかなり抑制することが可能であるが, 物理的に不可逆的 な膜ファウリングは定期的に物理洗浄を行っていても長 期運転においては徐々に僬行寸ることから，MBRの運転コ ストを下げるためには物理的に不可逆的な膜ファウリン グを抑制することが必要となる。

既往の研究において，MBRにおける膜ファウリングの進 行に影謷を及ぼす運転条件に関連した因子として、ばっ気 流量 ${ }^{6,7)}$, 逆流洗浄方法 ${ }^{8,9)}$, 膜透過水 $\mathrm{flux}^{7,10)}$ 等方指捅されて いる。また，使用する膜の材質を変えることによって膜フ アウリングの進行速度が大きく袈化することも明らかと なっている ${ }^{11)}$ 。単位微生物量当たりの有機物負荷 (food-to-microorganism ratio; F/M比) ${ }^{12)}$, 污洸滞留時間(sludge retention time; SRT $)^{8,13,14)}$, 污泥䟴度 ${ }^{7,15)}$ も活性污泥性状を変 化させることで膜ファウリングの進行に影幦を及ぼして いると考えられる。膜ファウリングの進行と関連性が高い 污泥性状の指標としては糖及びタンパク質謷度, 粘性, 粒 径分布等が指摘されている16-20)。しかし、これらの先行研 究例の多くにおいて生物分解性の高い有機物源を主体と 
寸る人工下水が流入原水として用いられているか，もしく は実験期閐が非常に短いため，これらの研究で得られた知 見が実際のMBRの運転に直接適用できるかどうかは必ず しも定かではない。Rosenbergerらは実下水を流入原水とす るMBRの長期連続運転を行い, 活性污泥面濁液中の非沈 降性画分に含まれる全鈢澸度の増減と膜ファウリング進 行速度の間に関連性があると報告している ${ }^{21) 。 ま た ， ~} \mathrm{Ng}$ らも実下水を流入原水とするMBRにおいてSRTを短く設 定することによって増加した非沈降性画分の全有機炭素 (total organic carbon; TOC) 疑度が膜ファウリング進行速度 に影響を及ぼすと結論付けている22)。しかし、これらの研 究では物理的に可逆的な膜ファウリングと物理的に不可 逆的な膜ファウリングの区別がなされていない。筆者らは， 物理的に可逆的な膜ファウリングと物理的に不可逆的な 膜ファウリングを明確に区別し，それぞれのタイプの膜フ アウリングに影響を及ぼす因子について実下水を用いた 長期奏験により検郡を行ったところ,物理的に不可逆的な 膜ファウリングの進行速度と反応槽内のTOC濒度や全糖 潡度といった包括的指標との間に関連性は観察されず23), 特定の有機成分が物理的に不可逆的な膜ファウリングの

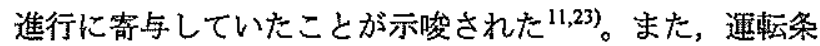
件を変化させることによって膜ファウリングの原因とな る物質(膜ファウリング物質)の特性が変化することも明ら かとなっている23)。

MBRにおける膜ファウリングの発生機椿を理解するに は, 膜ファウリングに寄与する成分の反応盙内に斿ける挙 钦及びその起源に関する情報が電要である。実下水処理を 行うMBRにおける膜ファウリング物質の起源としては, 微生物の死隇に伴って放出される有機物 (biomassassociated products; BAP)に加えて，微生物の基質代謝に伴 って放出される有機物(utilization-associated products; UAP) 及び流入原水中に含まれる有機物が考えられる ${ }^{24)}$ 。本研究 では，実下水を流入原水として運転条件の異なるMBRの 長期連続通転を行い, 運転条件と膜ファウリング物質特性 の関連性を調查すると同時に，流入原水中に含まれる有機 物及び各MBR反空槽内の活性污泥より生成したBAPの特 性解析を行うことで, 各運転条件における膜ファウリング 物質の起源に関して検討を行った。

\section{2. 实験方法}

\section{1 パイロットスケールMBRの連続運転}

札幌市創成川水再生プラザ内に設置したパイロットス ケールMBRを用いて，同処理場の最初沈殿池流入水を流 入原水とするMBRの連続ろ過運転を75日閒行った。実験 に用いたMBRは生物反応楷に中空糸膜モジュールを直接 浸漬させた単一槽型MBRである。本実験では2尙列のMBR を用い，SRTを変化させて実験を行った。各MBRの運転条 件をTable 1に示す。MBRIに㧍いては，有効容㔍175lの生 物反応榑に総膜面䄼 $1.3 \mathrm{~m}^{2}$ の膜モジュールを浸漬させてろ 過を行った。MBR2においては, 有効容積 350 lの生物反心 揹にMBR1で使用していたものと全く同一の膜モジュー ルを2組浸涜させて同時にろ過を行った。MBR2の反忘槽 に浸漬させていた2組の膜モジュールは膜透過水fluxを変 化させて $\left(0.4 \mathrm{~m}^{3} \cdot \mathrm{m}^{-2} \cdot \mathrm{day}^{-1}\right.$ と $\left.0.8 \mathrm{~m}^{3} \cdot \mathrm{m}^{-2} \cdot \mathrm{day}^{-1}\right)$ 万過を行 っていたが, 本論文では, 膜透過水fluxを $0.8 \mathrm{~m}^{3} \cdot \mathrm{m}^{-2} \cdot$ day $^{-1}$ に設定した系列のデータのみを使用している。両MBRに
Table 1 Operating conditions of MBRs.

\begin{tabular}{ccc}
\hline & MBR1 & MBR2 \\
\hline Permeate flux $\left(\mathrm{m}^{3} \cdot \mathrm{m}^{-2} \cdot\right.$ day-1 $\left.^{-1}\right)$ & 0.8 & 0.8 \\
HRT $(\mathrm{h})$ & 5 & 7 \\
SRT (day) & 15 & 67 \\
\hline
\end{tabular}

おけるSRTを設定值に調整するため，反応楷からの污泥の 引き抜きを週末を除き毎日行った。污泥の引き抜きは反应 㮐下部に取り付けられたドレンから行った。両MBRにお けるSRTをTable 1に示した值に設定した結果，MLSS湍度 はMBR1においては3 6 g・ $I^{-1}$, MBR2においては11 15 g・ I の間で変動し，平均健はMBR1及びMBR2においてそれ ぞれ $5 \mathrm{~g} \cdot l^{-1}$ 及び $13 \mathrm{~g} \cdot l^{1}$ であった。本実鈳で用いた膜(三菱 レイヨン製)忙公称孔经 $0.4 \mu \mathrm{m}$ のポリフッ化ビニリデン (polyvinylidene fluoride; PVDF)膜である。ろ過方式は膜透過 水fluxを $0.8 \mathrm{~m}^{3} \cdot \mathrm{m}^{-2} \cdot$ day $^{-1}$ に固定した定流量ろ過とし, 连 転/停止を組み合わせた間久運転(12分吸引ろ過一3分万過 停止)学行った。運転期間中，ろ過の運転/停止に関わらず 膜モジュール下部からのエアレーションを常時行った。

膜ファウリングが進行してろ過の継続が困難となった 場合には, 膜モジュールを反応槽から引き上げて加圧水の 吹きつけ及びスポンジを用いた膜表面の拭き取りによる 物理洗浄を行った。物理洗浄による膜透過性能の回復が十 分でなかった場合には, 引き続き膜モジュールを洗浄液に 約24時間浸漬させて蒋品洗浄を行った。薬品洗浄には，塩 酸 $(\mathrm{pH} 2)$ 及び次两塩素酸ナトリウム $(500 \mathrm{ppm})$ を用いた。

膜ファウリングの進行は以下の式から算出した全る過 抵抗を用いて評価した。

$$
J=\frac{\Delta P}{\eta R_{t}}=\frac{\Delta P}{\eta\left(R_{m}+R_{f}\right)}
$$

ここで, $J$ は膜透過水 flux $\left(\mathrm{m}^{3} \cdot \mathrm{m}^{-2} \cdot \mathrm{s}^{-1}\right), \Delta P$ は膜閒差圧 $(\mathrm{Pa})$, $\eta$ は膜透過水の粘性係数 $(\mathrm{Pa} \cdot \mathrm{s}), R_{t}$ は全万過抵抗 $\left(\mathrm{m}^{-1}\right), R_{m}$ 及びRfはそれぞれ膜自体が有するろ過抵抗 $\left(\mathrm{m}^{-1}\right)$ 及び膜つ

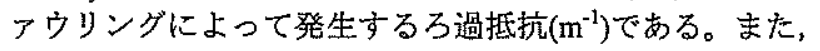
物理洗浄では解消できない物理的に不可逆的な膜ファウ リングの進行は, 物理洗浄直後の全ろ過抵抗值によって評 価した。

\section{2 連繞運転終了後の閉寒膜からの膜ファウリング物貿} の抽出

物理的に不可逆的な膜ファウリングを引き起こしてい た成分に関する情報を取得するため, 連続運転終了後に閉 塞獏からの膜ファウリング物質の抽出を行った。連続運転 終了後, 膜を膜モジュールより切り㜠し, 膜表面をスポン ジで拭き取った後，抽出処理に供した。抽出はpH 11の $\mathrm{NaOH}$ 水溶液に24時間樭汼しながら浸漬することによって 行った。抽出時の $\mathrm{NaOH}$ 水溶液の水温は $30^{\circ} \mathrm{C}$ 設定した。 なお, 本抽出処理を行った結果, 獏ファウリングに起因す る全ろ過抵抗が50\%程度減少することを確認している。24 時間経過後の $\mathrm{NaOH}$ 水溶液についてTOC, 全糖, 全タンパ ク質及び三次元励起蛍光スペクトル(excitation emission matrices; EEM)の測定を行った。抽出溶液の一部は電気透 析による脱塩を行った後, 凍結乾燥を施しフーリエ変换赤 外(Fourier transform infrared; FTIR)スペクトル分析に供し た。また，膜ファウリング物質の単糖及びアミノ酸棈成を 測定した。 


\section{3 膜つァウリング物犋の起源の推定}

都市下水処理を行うMBRにおける膜ファウリング物質 の起源としては，BAP，UAP及び原水中有機物が考えられ る。本研究では，このうち，BAPと原水中有機物を回収し 特性解析を行った。なお，UAPについては，BAP及び原水 中有機物の特性と膜ファウリング物質の特性を比較し， BAP及び原水中有機物以外の起源を有する有機物として 推定することとした。本研究では，污泥を好気的に分解し， 微生物を死诚させる過程において生成する有機物をBAP と定義した。污泥の分解は，容䆅 $500 \mathrm{~m} /$ の三角フラスコ内 に連続運転を行っているMBRから採取した污泥を約 300 $\mathrm{m} l$ 採取し，散気球を用いてエアレーションを長期間継続す ることにより行った。実験中，水位を維持するために添加 した超純水を除いては外部基質の添加を一切行わなか力

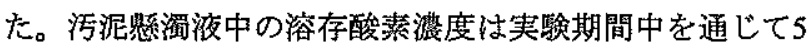
$\mathrm{mg} \cdot l^{-1}$ 以上であり，好気的な状態が維持されていた。また， 污泥の分解を行っている三角フラスコは恒温槽の中に設 置し，水温を一定に保った。本研究では，冬季間にMBR の連続運転を行ったため, 污泥分解時の水温は代表的な冬 季閒の水温である $10^{\circ} \mathrm{C}$ に設定した。各MBRのSRTに相当す る15日及び60日経過時に污泥留濁液を孔径 $0.5 \mu \mathrm{m}$ のPTFE 膜(ADVANTEC製)でろ過し, 各種分析に供することでBAP の特性解析を行った。

原水中有機物の特性を検討するため，MBRの流入原水 として用いた下水処理場の最初沈澱地流入水をコンポジ ット方式で採水した。本実験では，物理的に不可逆的な膜 ファウリングに関与する膜ファウリング物啠の起源を検 討対象としていることから，流入原水中に含まれる有機物 のうち物理的に不可逆的な膜ファウリングを直接引き起 こす可能性のある溶解性成分について特性解析を行うた め，採取した流入原水を $0.5 \mu \mathrm{m}$ のPTFE膜(ADVANTEC製) でろ過した後，各種分析に供した。BAP及び原水中有機物 それぞれについて，前述した膜ファウリング物質と同様の 分析を行った。

\section{4 分析手法}

TOC灌度はTOC計(TOC-V; Shimadzu)を用いて測定した。 活性污泥留溜液中の溶存性有機炭素 (dissolved organic carbon; DOC)警度の測定においては，前処理として試料を $0.5 \mu \mathrm{m} の$ PTFE膜(ADVANTEC製)でろ過した後，TOC計に よる測定に供した。MLSS漄度の測定は下水道試験法に準 起して行った ${ }^{25)}$ 。全楉整度はグルコースを標準物翼とした フェノール硫酸法 ${ }^{26)}$, 全タンパク質䔝度はアルブミンを標 淮物質としたLowry法27によってそれぞれ湘定した。FTIR スペクトル分析においては，陚料を $0.25 \%$ 含むKBrペレッ 卜定作成L，FTIR分光計(FTIR-8400S; Shimadzu)妾用いて 解像度 $4 \mathrm{~cm}^{-1}$, 反復回数 360 回で測定した。EEMは150 Wの キセノンランプを装着した蛍光分光計(RF-5300PC; Shimadzu)を用いて測定した。EEM測定においては，試料 を孔径 $0.5 \mu \mathrm{m}$ の膜でろ過した後, 超純水を用いて試料を波 長 $300 \mathrm{~nm}$ における吸光度が 0.02 以下となるように希䣋し $た^{28)}$ 。

単精攉成の分析は, パルスドアンペロメトリ検出器を装 着したHPLC (DX 500; Dionex)を用いて行った。HPLCによ

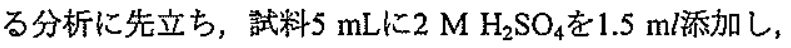
$100^{\circ} \mathrm{C}$ で 5 時間加熱することによって加水分解を行った。加 水分解後の試料に対し, $\mathrm{BaCO}_{3}$ を $1 \mathrm{~g}$ 添加寸ることで溶液中
に残存した硫酸イオンを除去したのち，HPLCによる分析 に供した。使用したカラムは，陰イオン交換力ラムである Dionex Carbopac PA1であり，移動相としては18 mM NaOH 水溶液を使用した。また, 測定時のカラムの温度は $30^{\circ} \mathrm{C} に$ 設定し，移動相は流速 $1.0 \mathrm{ml} \cdot \mathrm{min}^{-1}$ でカラムに通水した。 Waters社から市販されているAccQ-Tag試蒋を用いた 「AccQ-Tagアミノ酸分析法」に従い各種有機物のアミノ 酸構成を測定した。測定試料はあらかじめ凍結乾㰒により 乾燥させたのち, 塩酸を用いて低圧下 $100^{\circ} \mathrm{C} て ゙ 20$ 時間の加 水分解処理を行った。その後, AccQ-Tag試薬を用いた誘 導体化処理を行い, AccQ-Tag力ラム(Waters)及び蛍光検出 器(L-7480; HITACHI)を装着したHPLCを用いて分析を行 った。

\section{3. 結果上考察}

\section{1 パイロットスケールMBRにおける全ろ過抵抗の変化}

Fig. 1にMBRの連続運転における全ろ過抵抗の経日変化 を示す。図中の細い矢印は物理洗浄,太心矢印は薬品洗浄 の㥶施時期を, 破線は物理洗浄では解消できない物理的に 不可逆的な膜ファウリングの進行をそれぞれ示す。SRTを 短く設定したMBR1においては，運転開始から運転15日目 付近までは膜ファウリングの進行は比較的緩やかであっ たが，運転15日目以降において全ろ過抵抗が急激に增加し た。運転19日目にはMBR1におりる膜ファウリングが著し く進行し，運転の継続が困難となったため，膜モジュール を反応榑より引き上げて物理洗浄を行った。物理洗浄によ って膜透過性能は回復したが, 運転開始当初の值までは回 復しなかった。運転19日目の物理洗浄実施後においても， 急激な膜ファウリングが繰り返し観察され，物理洗浄を繰 り返し実施した後, 運転31日目には物理洗浄による膜透過 性能の回復程度が十分ではなかったことから薬品洗浄を 実施した。薬品洗浄によって, 膜透過性能は運転開始当初 とほぼ同等程度まで回復した。楽品洗浄実施後においても， MBR1においては急激な膜ファウリングが絽り返し観察 され，連続運転終了までの間にさらに6度の物理洗浄を実 施した。Fig. 1中の破線の傾きより算出したMBR1における

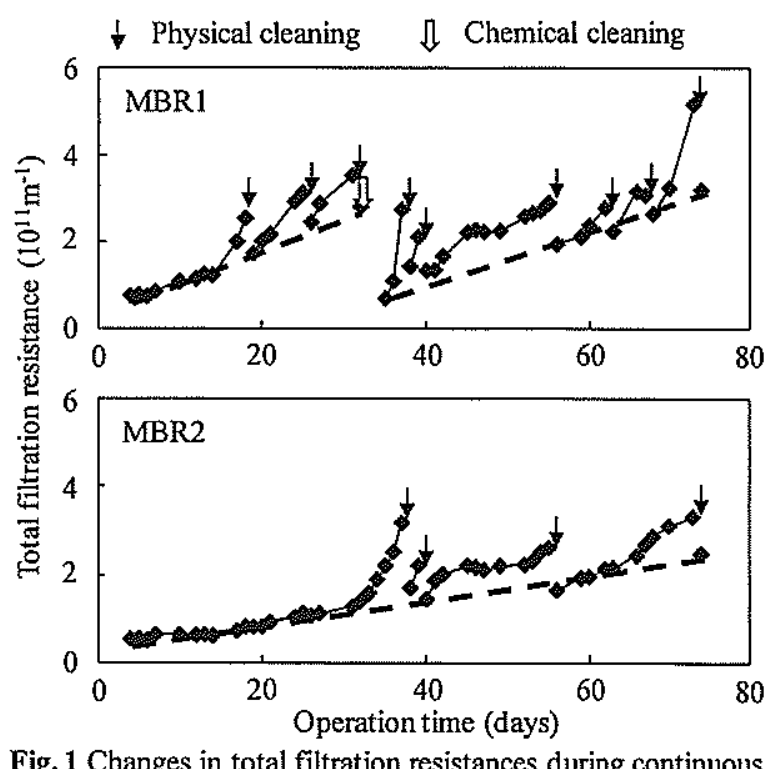

Fig. 1 Changes in total filtration resistances during continuous operation of MBRs. 
物理的に不可逆的な膜ファウリングの進行速度は, 運転31 日目に実施した薬品洗浄前後においてそれぞれ $7.3 \times 10^{9}$ $\mathrm{m}^{-1} \mathrm{day}^{-1}$ 及び $6.4 \times 10^{9} \mathrm{~m}^{-1} \mathrm{day}^{-1}$ であった。MBR1では，連続 運転期間を通じて物理的に不可逆的な膜ファウリングの 進行速度に大きな変動はなかったことが示されている。

SRTを長く設定したMBR2においては，運転開始から運 転30日目付近まで非常に安定した運転が可能であったが， 運転30日目加ら運転40日目の期間において急激に膜ファ ウリングが進行した。運転38日目及び運転40日目に実施し た物理洗浄の結果, 膜透過性能が大きく回復したことから， この時期にMBR2において発現していた膜ファウリング は物理的に可逆的な膜ファウリングによるものであった ことが明らかである。MBR2においては連続運転期閒中に 計4回の物理洗浄を実施したが，物理的に不可逆的な膜フ アウリングの進行を表すFig. 1中の破線の傾きは連続運転 期間中を通じてほぼ一定であったと判断される。MBR1と 同憡に，MBR2においても連続運転期閒中を通じて物理的 に不可逆的な膜ファウリングの進行速度に大きな变動は なかったものと考えられる。Fig. 1中の破線の傾きから算 出されるMBR2における物理的に不可逆的な膜ファウリ ングの進行速度 $\left(2.8 \times 10^{9} \mathrm{~m}^{-1} \mathrm{day}^{-1}\right)$ はMBR1の2分の1以下で あった。実都市下水処理を行うMBRにおいては, SRTを短 く設定することによって物理的に不可逆的な膜ファウリ ングが進行しやすくなることをすでに報告しているが23), 本研究においても同様の結果が得られた。

\section{2 膜ファウリング物覧の抽出}

Table 2に連続運転終了後の閉塞膜からのTOC, 糖, 夕 ンバク質の抽出貿を示す。連続運転終了時における物理的 に不可逆的なる過抵抗はMBR1においてより大きかった にも関わらず, MBR2に使用していた膜からはMBR1に使 用していたものと比較してより多舅の有機物が抽出され た。また，両MBRに使用していた膜からの全瞊及び全夕 ンパク質抽出黄の測定を行ったところ，MBR1の膜ファウ リング物犋におけるTOC中に占める糖及びタンパク質の 割合はMBR2の膜ファウリング物質と比較して高く，両 MBRから抽出された膜ファウリング物㙃の特性の間に差 異が認められる。MBRにおける物理的に不可逆的な膜フ アウリングの発生においては, 膜への有機物の吸着量では なく膜ファウリングに関与する有機物の特性が重要であ り，膜ファウリング物質の特性が異なることにより膜ファ ウリング物質が単位吸着量当たりに発現させるる過抵抗 が異なっていた可能性が示唆される。

\section{3 篹ファウリング物筫の起源の探索}

上述したように，SRTを変化させた2つのMBRでは特性 の異なる有機物が膜ファウリングに関与しており，それぞ れの膜ファウリング物質が単位昅着量当たりに発現させ るろ過抵抗が異なっていた可能性が考えられた。そこで, 膜ファウリング物質の特性に差巽が生じた原因について 検討を行うため, 膜ファウリング物盺のより詳細な特性を

Table 2 Characteristics of foulants desorbed from the fouled membranes.

\begin{tabular}{cccc}
\multicolumn{2}{c}{$\begin{array}{c}\text { TOC } \\
\left(\mathrm{mg}-\mathrm{C} \cdot \mathrm{m}^{-2}\right)\end{array}$} & $\begin{array}{c}\text { Carbohydrate } \\
\left(\mathrm{mg}-\mathrm{C} \cdot \mathrm{m}^{-2}\right)\end{array}$ & $\begin{array}{c}\text { Protein } \\
\left(\mathrm{mg}-\mathrm{C} \cdot \mathrm{m}^{-2}\right)\end{array}$ \\
\hline MBR1 & 17.9 & 9.3 & 7.6 \\
MBR2 & 36.2 & 12.7 & 13.3 \\
\hline
\end{tabular}
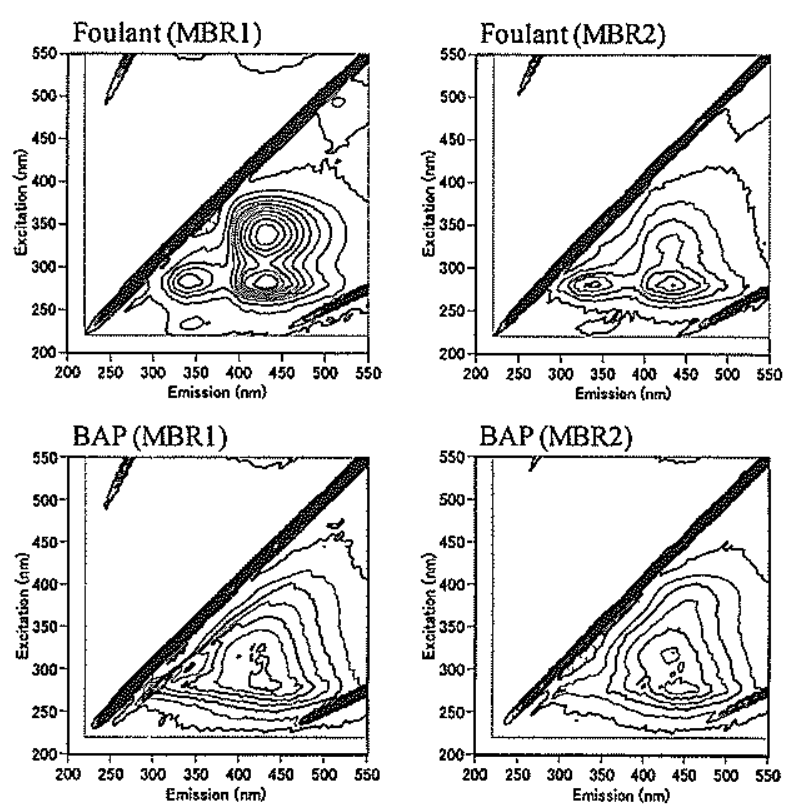

Organic matter contained

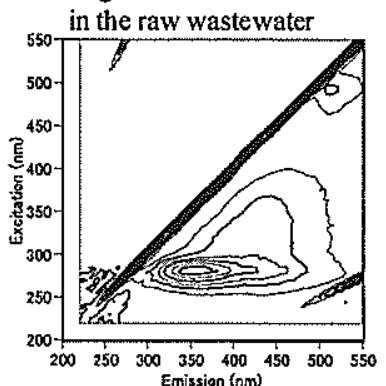

Fig. 2 Fluorescence EEM of foulants, BAPs and organic matter contained in the raw wastewater

調べるとともに，これらをBAP及び原水中有機物の特性と 比較することで，それぞれのMBRにおける膜ファウリン グ物質の起源に関して検郡を行った。

3.3.1 膜ファウリング物筧, BAP, 原水中有機物のEEM

Fig. 2に両MBRの膜ファウリング物質，BAP及び原水中 有機物について测定したEEMを示す。EEMにおける340 $\mathrm{nm} / 425 \mathrm{~nm}(\mathrm{Ex} / \mathrm{Em}$; 以下も同様)及び $275 \mathrm{~nm} / 425 \mathrm{~nm}$ に位䁂 するピークはともにフミン質様物質に起因するピークで あり，275 nm/350 nmに位頤するピークはタンパク質様物

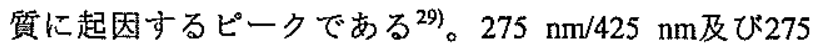
$\mathrm{nm} / 350 \mathrm{~nm}$ に位置寸るピークは，両MBRの膜ファウリング 物質のEEMにおいて共通して顕著であった。一方で， 340 $\mathrm{nm} / 425 \mathrm{nmk}$ 位置するピークについてはMBR1の膜ファウ リング物質のEEMにおいては顕著であったが, MBR2の膜 ファウリング物質のEEMではほとんど認められない。この 結果は, 両MBRの膜ファウリング物犋の特性が異なって いたことを示すものであり，MBR1の膜ファウリング物質 中におけるフミン質様物質の存在割合はMBR2と比較し て高かったことを示唆するものである。

BAPについて測定したEEMでは，いずれのEEMにおい てもフミン質様物質に起因するピークが顕著であった。 BAPにはフミン質㥞物質と特性が類似した有機物が含ま れているものと考えられる。原水中有機成分については， タンパク質橧物質に起因する $275 \mathrm{~nm} / 350 \mathrm{~nm}$ のピークが卓 越していた。この傾向は，連続運転期間中に行ったすべて 
の測定で一賛していた $(\mathrm{n}=4)$ 。

両MBRの膜ファウリング物質とBAP及び原水中有機物 のEEMを比較すると，BAPに特徴的であったフミン質様物 質に起因するピークは，雨MBRの膜ファウリング物竹の 場合でも認められる。しかし，MBR1の膜ファウリング物 翼について測定したEEMではフミン镇様物啠に起因する2 つのピークが明確に分雄されていたのに対し，BAPのEEM においては340 nm/425 nm付近の大きなピークが認められ るのみである。MBR1の膜ファウリング物質に含まれるフ ミン質様物質は，BAPに含まれるフミン質様物質とは特性 が異なるものであった可能性が考えられる。原水中有機物 について測定したEEMにおいてはフミン質様物質に起因 するピークがほとんど諗められないことから，MBR1の膜 ファウリング物質に含まれるフミン質様物質はUAPに起 因するものであったと判断される。一方，MBR2の膜ファ ウリング物澌について測定したEEMにおいては,フミン質 様物質に起因する2つのピークが完全に分離されておらず， BAPのEEMとの閒に一定の類似性が認められる。MBR2に おいてはBAPに由来する有機物の膜ファウリングへの察 与度が高かった可能性が示唆される。タンパク質様物質に 起因するピークは，両MBRの膜ファウリング物䓄につい て測定したEEMに共通して顥著であった。このピークは, 原水中有機物のEEMにおいても顕著であった一方で, BAP について测定したすへてのEEMにおいて明確なピークと はなっていなかったことから，膜ファウリング物質のEEM において認められるタンパク質様物質に起因するピーク がBAPに由来するものであった可能性は低いと考えられ る。兩MBRに括いて膜ファウリングに関与していたタン パク犋様物質の起源として原水中有機物もしくはUAPが 考えられるが，この点に関しては，後述する各種有機物の アミノ酸柾成を踏まえたうえで検討を行う。

\subsection{2 膜ファウリング物筧，BAP，原水中有機物のFTIRスペ} クトル

Fig. 3に雨MBRより抽出した膜ファウリング物顊，BAP 及び原水中有機物について測定したFTIRスペクトルを示 す。原水中有機物のFTIRスペクトルに䦔しては，EEMの 場合と同様に測定したすべてのスペクトルに類似性が認 められた $(\mathrm{n}=3)$ 。膜ファウリング物質のFTIRスペクトルに 着目すると，いずれのスペクトルにおいても1,000-1,100 $\mathrm{cm}^{-1}$ に位置するピークが顕著であった。このピークはC-O 伸縮に起因するピークであり ${ }^{30,31)}$ ，膜ファウリング物質中 に含まれる成分では, 多榶類様物䆩と関連付けることがで きる。また， $1,660 \mathrm{~cm}^{-1}$ 及び1,540 $\mathrm{cm}^{-1}$ 付近のピークも，两 MBRから抽出した膜ファウリング物缶のFTIRスペクトル において共通して顕著であった。こいらのピークはをれぞ れamide-1結合及びamide-2結合に起因するピークであるこ

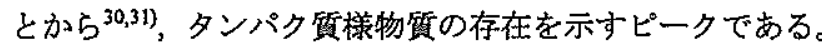
これらの結果は, 多糖類様物質及びタンパク質様物筫が連 続運轱におけるSRTに関わらず膜ファウリングの進行に 奇与していたことを示している。一方で，両MBRから抽 出した膜ファウリング物顊のFTIRスペクトルにおける, 1,300-1,500 $\mathrm{cm}^{-1}$ に位置するピークには大きな差異が諮め られた。このピークはフミン質様物斦において特徴的に観 察されるピークであり ${ }^{32)}$, MBR1の膜ファウリング物啠中 においてフミン質様物䆩の存在割合が高かったことを示 唆するものである。この結果は，上述したEEMの結果とも

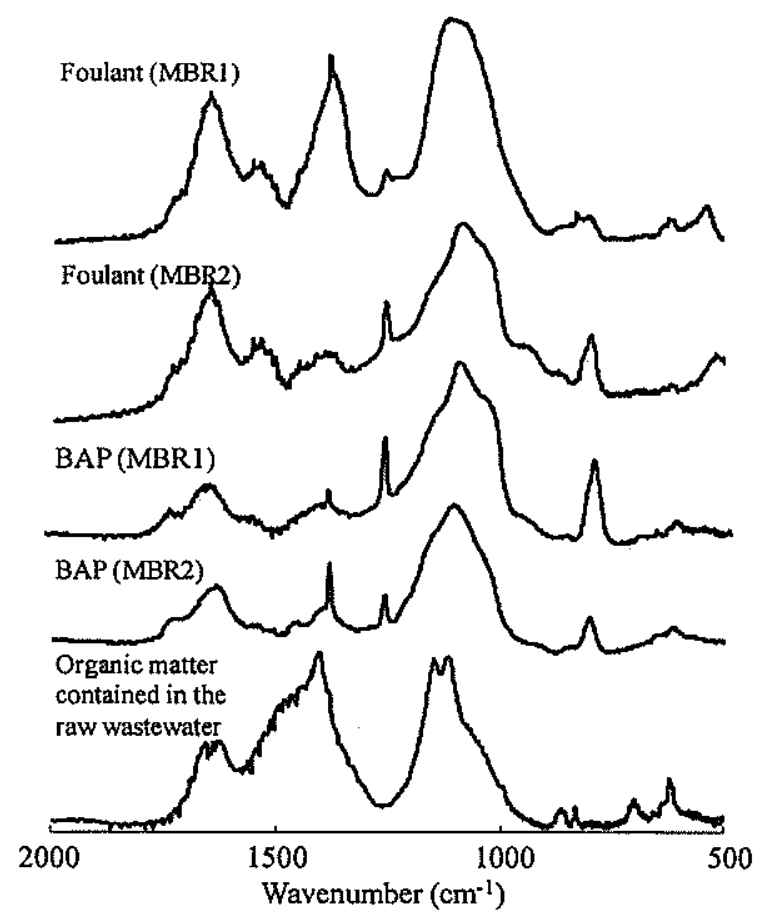

Fig. 3 FTIR spectra of foulants, BAPs and organic matter contained in the raw wastewater

符合するものであり，連続運転におけるSRTを変化させる ことによって, 膜ファウリング物眞の特性が変化したこと が明らかである。BAPのFTIRスペクトルにおいては, 1,380 $\mathrm{cm}^{-1}$ 付近に鋭いピークが認められるが,このピークは污泥 の分解中に生成した硝酸性空素に起因するものである。各 BAPについて測定したFTIRスペクトルについては,いずれ のスペクトルにおいても多糖類様物質に起因する 1,000*1,100 $\mathrm{cm}^{-1}$ に位琶するピークが他のピークに対して 卓越しており，BAPは多糖類様の特性を強く示すことが明 らかとなった。

両MBRの膜ファウリング物質とBAP及ざ原水中有機物 のFTIRスペクトルを比較すると，原水中有機物のFTIRス ペクトルは膜ファウリング物質のものと明らかに形状が 異なっており，原水中有機物の膜ファウリングへの関与度 は低いものと考えられる。タンパク萝様物質に起因する $1,540 \mathrm{~cm}^{-1}$ 付近のピークは雨MBRから抽出した膜ファウリ ング物資のFTIRスペクトルにおいて共通して影著であっ たが, BAPについて測定したFTIRスペクトルにおいてはこ の部分に明確なと゚ークが認められなかった。この結果は， いずれのMBRにおいてもBAP以外の成分に由来するタン パク質様物颖が膜ファウリングに関与していたことを示 唆しており，EEMの結果と符合するものである。MBR2に ついては，上述したタンパク買様物質に起因するピークの 大きさに差異が㤎められたものの，膜ファウリング物質と BAPのFTIRスペクトルの間に一定の類似性が認められる。 MBR2においては, BAPの膜ファウリングへの宗与度が大 きかった可能性が考えられる。一方，MBR1に関しては， 膜ファウリング物質とBAPのFTIRスペクトルの間に MBR2の場合のような類似性は認められず，MBR1の膜フ アウリング物質中に占めるBAPに由来する有機物の割合 は低かったものと推察される。さらに, MBR1の膜ファウ リング物質においてのみ顕著であった1,300-1,500 $\mathrm{cm}^{-1} に$ 


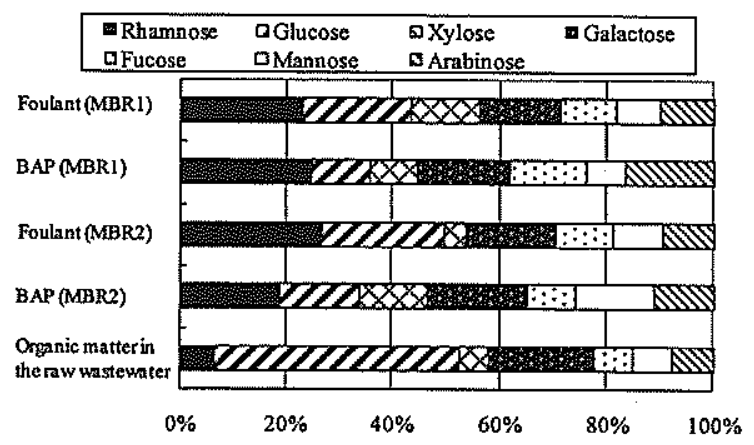

Fig. 4 Monosaccharide compositions of foulants, BAPs and organic matter contained in the raw wastewater

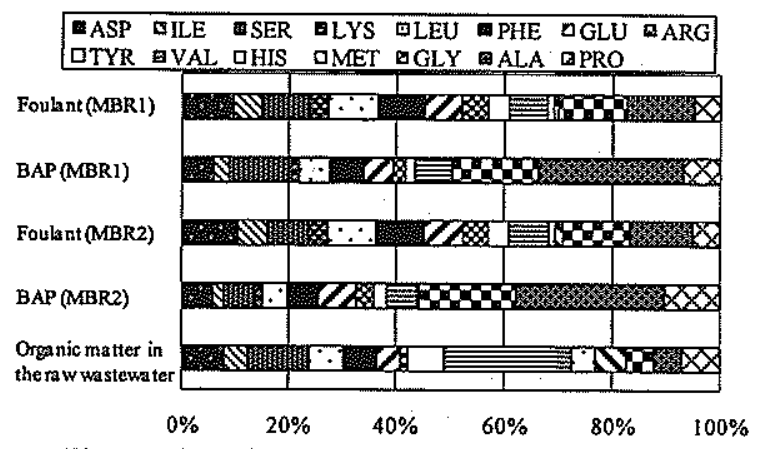

Fig. 5 Amino-acid compositions of foulants, BAPs and organic matter contained in the raw wastewater

位圆するピークに関しても，BAP及び原水中有機物のFTIR スペクトルにおいて類似したピークは観察されなかった ことから、このピークはUAPに由来する有機物に起因する ものであると考えられる。MBR1においては，UAPが膜フ アウリングの進行に大きく寄与していた可能性が示唆さ 机る。

\subsection{3 膜ファウリング物資，BAP，原水中有機物の単糖及 びアミノ酸構成}

Fig. 4及びFig.5に膜ファウリング物質，BAP及び原水中 有機物の単糖及びアミノ酸構成を示す。原水中有機物之膜 ファウリング物質の单楉構成を比較すると, グルコースの 存在割合が原水中有機物において明らかに高くなってお り，両者に類似性沖認められない。流入原水中に含まれる 糖が植接膜ファウリングへ寄与する度合は大きくなかっ たものと考えられる。膜ファウリング物質とBAPの単糖構 成の此較においては，いずれのMBRにおいても膜ファウ リング物質中でグルコースの存在割合が高くなっていた が，两MBRとも膜ファウリング物質とBAPの単糖構成に 明確な差異は認められない。両MBRにおいてBAPに由来 する糖の膜ファウリングへの等与度が高かった可能性が 考えられるが, UAP及びBAPの単楉模成にも明確な差異が なく, 結果としていずれのMBRにおいても膜ファウリン グ物質とBAPの単糖粠成が類似したものとなっていた可 能性も否定することができない。本研究の結果からは䒽 MBRの膜ファウリング物質に含まれる糖がUAPもしくは BAPのどちらに由来しているのかを判断するのは困難で ある。

各種有機物のアミノ酸構成については，いずれのMBR においてもBAPと膜ファウリング物質のアミノ酸杽成は 大きく異なっていたが，この結果はBAP以外の成分に由来
するタンパク質が膜ファウリングの進行に関与していた とする上述のEEM及びFTIRスペクトル分析に基づく検討 結果を支持するものである。一方で，EEM分析においては 流入原水中に含まれるタンパク質が膜ファウリングに関 与していた可能性が示唆されたが, 膜ファウリング物質と 原水中有機物のアミノ酸構成を比較したところ, 両者に類 似性は認められなかった，原水中有機物に由来するタンパ ク質が直接膜ファウリングに関与した可能性は低いと考 えられる。雨MBRから抽出した膜ファウリング物質の EEMにおいて認められたタンパク質様物質に起因するピ ークがBAPのEEMにおいて認められなかったことから、こ のピークはUAPに由来する成分に起因していたものと判 断される。膜ファウリングに関与していたタンパク質につ いては，いずれのMBRにおいてもUAPに由来する成分の 寄与度が大きかったものと推察される。

3.3.4 両MBRにおける膜つアウリング物質の起源

MBR1においては, 膜ファウリング物質のEEM及びFTIR スペクトルの形状がBAP及び原水中有機物と大きく異な っており，UAPが物理的に不可逆的な膜ファウリング進行 一支配的に奇与していたものと考えられる。一方, MBR2 においては，前節で述べた通りUAPに由来するタンパク質 が物理的に不可逆的な膜ファウリングの進行に笴与して いた可能性が考えられたものの，MBR2の膜ファウリング 物質とBAPのEEM及びFTIRスペクトルには一定の類似性 が認められた。MBR2においてはBAPの物理的に不可逆的 な膜ファウリングへの答与度がMBR1 と比較して大きか ったものと考えられる。本研究では，SRTの異なる2系列 のMBRを運転したが, Table 1に示したように, SRTを長 く設定したMBR2において污泥䜘度が高くなった。Barker らによると，BAPの生成速度は反応槽内の菌体瀇度に比例 することから ${ }^{33)}$ ，MBR2においてBAPがより多量に存在し ていたものと考えられる。しかし，MBR1及びMBR2の活 性污泥晒濁液中に含まれるDOCの連続運転期間中の平均 㴚度はそれぞれ $7.3 \mathrm{mg}-\mathrm{C} \cdot l^{-1}$ 及び $4.3 \mathrm{mg}-\mathrm{C} \cdot l^{1}$ であり，MBRI において高くなっていた。MBRにおける有機物の起源と しては，BAP，UAP及び原水中有機物が考えられるが，本 研究では，両MBRに同一の流入原水を導入していたこと から，両MBR間における反応槽内DOC灌度の差異が流入 原水に起因していた可能性は排除寸ることができる。また， BAPについても上述したように污混浱度が高かった MBR2においてより存在量が多かったものと考えられる。 以上のことを勘案すると, MBR1における反応槽内DOC畠 度の增加はUAPの蓄積に起因しているものと考えられる。 このことは, MBRの連続通転においては，SRTを短く設定 することによってUAPが蓄積しやすくなる可能性を示唆 するものである。

本研究では，活性污泥眧濁液中におけるUAPの蓄楮量が 多く、UAPが膜ファウリングの進行に支配的に笴与してい たと考えられたMBR1において物理的に不可逆的な膜フ アウリングの進行が速く, 同時に膜ファウリング物質が単 位吸着量当たりに発現させるろ過抵抗值も大きかった。一

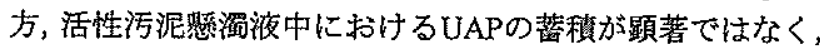
膜ファウリング物質中に占めるUAPの割合がMBR1と比 較して低かったと考えられるMBR2においては，物理的に 不可逆的な膜ファウリングがMBR1と比較して眭微であ り，また，膜ファウリング物質が単位吸着量当たりに発現 
させるろ過抵抗值もMBR1と比較して小さかった。これら の結果から，UAPが膜ファウリングの進行に関与すること で，大きなろ過抵抗を発現させていたと考えられる。都市 下水を処理するMBRにおける物理的に不可逆的な膜ファ ウリングを抑制するためには，反応槽内における過剩な UAPの蓄積を抑制することが肝要であり，UAPの蓄積を助 長する可能性のあるSRTの短い条件は避けるべきである。

\section{4. 結 論}

本研究では，都市下水処理を行うMBRの運転条件と膜 ファウリング物質特性の関連及びそれぞれの運転条件に おける膜ファウリング物質の起源に関して検討を行った。 実都市下水を流入原水とするMBRにおいては，SRTを短縮 することによって物理的に不可逆的な膜ファウリングの 進行が速くなった。また, 膜ファウリング物質の単位吸着 量当たりのろ過抵抗値はSRTの短い条件では高くなった。 それぞれの運転条件における膜ファウリング物質の起源 について検討を行ったところ, 流入原水中に含まれる有機 物に関しては, 有機物特性が膜ファウリング物質のものと 大きく異なっており，流入原水中に含まれる有機物が直接 膜を閣塞させていた可能性は低いものと判断された。物理 的に不可逆的な膜ファウリングが顕著であり，膜ファウリ ング物質が単位吸着量当たりに発現させるる過抵抗值が 大きかったSRTの短い条件では，UAPが物理的に不可逆的 な膜ファウリングへ支配的に奇与していたと考えられた。 物理的に不可逆的な膜ファウリングが軽微で, 膜ファウリ ング物質が単位吸着量当たりに発現させるろ過抵抗值が 小さかったSRTの長い条件では，UAPの物理的に不可逆的 な膜ファウリングへの寄与率が低くなり，BAPの物理的に 不可逆的な膜ファウリングへの寄与がかなりあったもの と考えられた。本研究の結果から, UAPはBAP及び原水中 有機物と比較してMBRにおける物理的に不可逆的な膜フ アウリングを引き起こしやすい特性を有している可能性 が示唆され，MBRの運転においてはUAPの著督を助長す るSRTの短い条件は避けるべきであると考えられる。

\section{參考 文 献}

1) Stephenson, T., Judd, S., Jefferson, B. and Brindle, K. (2000) Membrane bioreactors for wastewater treatment, IWA publishing, London.

2) Rosenberger, S., Kruger, U., Witzig, R., Manz, W., Szewzyk, U. and Kraume, M. (2002) Performance of a bioreactor with submerged membranes for aerobic treatment of municipal wastewater, Water Res., 36, 413-420.

3) Yamamoto, K., Hiasa, M., Mahood, T. and Matsuo, T. (1989) Direct solid-liquid separation using hollow fiber membrane in an activated sludge aeration tank, Wat. Sci. Tech, 21 (4-5), 43-54.

4) Kimura, K., Hara, H. and Watanabe, Y. (2005) Removal of pharmaceutical compounds by submerged membrane bioreactors (MBRs), Desalination, 178, 135-140.

5) Chang, I., S., Clech, P., L., Jefferson, B. and Judd, S. (2002) Membrane fouling in membrane bioreactors for wastewater treatment, $J$. Environ. Eng., 128, 1018-1029.

6) Howell, J., A., Chua, H., C. and Amot, T., C. (2002) In situ manipulation of critical flux in a submerged membrane bioreactor using variable aeration rates and effects of membrane history, J. Mem. Sci., 242, 13-19.

7) Germain, E., Stephenson, T. and Pearce, P. (2005) Biomass characteristics and membrane aeration: toward a better understanding of membrane fouling in submerged membrane bioreactors (MBRs), Biotech. and Bioeng., 90, 316-322.

8) Bouhabila, E., H., Aim, R., B. and Buisson, H. (2001) Fouling characterization in membrane bioreactors, Sep. Purif. Tech., 51, 95-103.

9) Psoch, C. and Schiewer, S. (2005) Critical flux aspect of air sparging and backflushing on membrane bioreactors, Desalination, 175, 61-71.

10) Guglielmi, G., Chiarani, D., Judd S., J. And Andreottola, G. (2007) Flux criticality and sustainability in a hollow fibre submerged membrane bioreactor for municipal wastewater treatment, J. Mem. Sci., 289, 241-248.

11) Yamato, N., Kimura, K., Miyoshi, T. and Watanabe, Y. (2006) Difference in membrane fouling in membrane bioreactors (MBRs) caused by membrane polymer materials, J. Mem. Sci, 280, 911-919.

12) Trussell, R., S., Merlo, R., P., Hermanowicz, S., W. and Jenkins, D. (2006) The effect of organic loading on process performance and membrane fouling in a submerged membrane bioreactor treating municipal wastewater, Water Res, 40, 2675-2683.

13) Grelier, P., Rosenberger, S. and Pain, A., T. (2006) Influence of sludge retention time on membrane bioreactor hydraulic performance, Desalination, 192, 10-17.

14) Liang, S., Liu, C. and Song, L. (2007) Soluble microbial products in membrane bioreactor operation: behaviors, characteristics, and fouling potential, Water Res., 41, 95-101.

15) Meng, F., Zhang, H., Yang, F., Zhang, S., Li Y. and Zhang, X. (2006) Identification of activated sludge properties affecting membrane fouling in submerged membrane bioreactors, Sep. Purif. Tech, 51, 95-103.

16) Rosenberger, S., Evenblij, H., te Poele, S., Wintgens, T. and Laabs, C. (2005) The importance of liquid phase analyses to understand fouling in membrane assisted activated sludge processes - six case studies of different European research groups, J. Mem. Sci., 263, 113-126.

17) Drew, A., Vocks, M., Iverson, V., Lesjean, B. and Kraume, M. (2006) Influence of unsteady membrane bioreactor operation on EPS formation and filtration resistance, Desalination, 192, 1-9.

18) Nagaoka, H., Ueda, S. and Miya, A. (1996) Influence of bacterial extracellular polymers on the membrane separation activated sludge process, Wat. Sci. Tech., 34 (9), 165-172.

19) Meng, F., Zhang, H., Yang, F., Zhang, S., Li, Y. and Zhang, X. (2006) Identification of activated sludge properties affecting membrane fouling in submerged membrane bioreactors, Sep. Purif., Tech. 51, 95-103.

20) Watanabe, Y., Kimura, K. and Itonaga, T. (2006) Influence of dissolved organic carbon and suspension viscosity on membrane fouling in submerged membrane bioreactor, Sep. Sci. Tech., 41 (7), 1371-1382.

21) Rosenberger, S., Laabs, C., Lesjean, B., Gnirss, R, Amy, G., Jekel, M. and Schrotter, J. -C. (2006) Impact of colloidal and soluble organic material on membrane performance in membrane bioreactors for municipal wastewater treatment, Water Res., 40, 710-720.

22) Ng, H., Y., Tan, T., W. and Ong, S., L. (2006) Membrane fouling of submerged membrane bioreactors: impact of mean cell residence time and the contributing factors, Environ. Sci. Tech., 40, 2706-2713.

23) Kimura, K., Yamato, N., Yamamura, H. and Watanabe, Y. (2005) Membrane fouling in pilot-scale mambrane bioreactors (MBRs) treating municipal wastewater, Environ. Sci. Tech., 39, 6293-6299.

24) Laspidou, C., S. and Rittmann, B., E. (2002) A unified theory for extracellular polymeric substances, soluble microbial products, and active and inert biomass, Water Res., 36, 2711-2720.

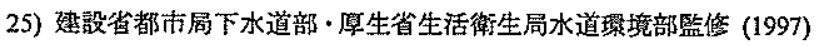
下水詿䭆方法(上巻)，社団法人日本下水道協会, 東京.

26) Dubois, M., Gilles, K., A., Hamilton, J., K., Rebers, P., A. and Smith, F, (1956) Colorimetric determination of sugars and related substances, Anal. Chem., 28, 350-356.

27) Lowry, O., H., Rosebrough, N., J., Farr, A., L. and Randall, R., J. (1951) 
Protein measurement with the Folin phenol reagent, J. Biol. Chem., 193, 265-275.

28) Green, S., A. and Blough, N., V. (1994) Optical absorption and fluorescence properties of chromophoric dissolved organic matter in natural waters, Limnol. Oceanogr., 39 (8), 1903-1916.

29) Chen, W., Westerhoff, P., Leenheer, J., A. and Booksh, K. (2003) Fluorescence excitation-emission matrix regional integration to quantify spectra for dissolved organic matter, Environ. Sci. Tech., 37, 5701-5710.

30) Barber, L., B., Leenheer, J., A., Noyes, T., I. and Stiles, E., A. (2001) Nature and transformation of dissolved organic matter in treatment wetlands, Environ. Sci. Tech., 35, 4805-4816.

31) Croue, J., P., Benedetti, M., F., Violleau, D. and Leenheer, J., A. (2003) Characterization and copper binding of humic and nonhumic organic matter isolated from the south platte river: evidence for the presence of nitrogenous binding site, Environ. Sci. Tech., 37, 328-336.

32) Stevenson, F., J. and Goh, K., M. (1971) Infrared spectra of humic acids and related substances, Geochim. Cosmochim. Acta, 35, 471-488.

33) Barker, D., J. and Stuckey, D., C. (1999) A review of soluble microbial products (SMP) in wastewater treatment systems, Water Res., 33, 3063-3082. 